\title{
FEDERAL LEGISLATION AND COMMON LAW ASPECTS OF ENVIRONMENTAL PROBLEMS IN CANADA
}

\author{
BERNARD L. STROPPA*
}

Because of the ever increasing concern of mankind over the protection of his environment, greater emphasis has been placed, both in legislation and in the development of the common law, on providing answers and remedies to the problem of pollution. In this survey of the law, the author lists and discusses the Federal legislation which applies to the problem of pollution control. The discussion is broken into six topics, each dealing with a particular geographical area of Canada, including one on air pollution. Particular emphasis is put on legislation respecting pollution of waters by the resource industries. Following that, the author discusses six possible remedies available at common law, with particular reference to nuisance actions. The author concludes that the legislative field is likely to be the most productive of solutions.

\section{INTRODUCTION}

The purpose of this paper is to review various issues and problems that may arise out of different phases of petroleum industry activity and which may be covered by what is loosely referred to as Environmental Law. For comparative purposes a summary was included elsewhere in this issue of what is believed to be the most important recent developments in this field in the United States.

Environmental law covers a wide range of rights and remedies under the common law such as nuisance (public and private), negligence, and the narrow body of law associated with the case of Rylands v. Fletcher. In addition, there is voluminous legislation, both Federal and Provincial, which concerns, and is co-extensive with, every aspect of the common law remedies as noted. The problem of sorting out which laws apply is further compounded by the broadness of the subject matter, mostly undefined, but generally understood as being any matter or thing affecting land, air and water which is disagreeable, harmful, annoying, etc. at various times, by various people and for various reasons.

For the purposes of this paper, it is hoped merely to raise the questions and issues in as many areas as possible without attempting to provide an exhaustive analysis of any single area. It is felt that a checklist of trouble spots will be most useful as a beginning for further research.

Common law remedies in Canada are added to this portion of the paper since the direction of environmental laws is still open here. In the common law review there is no attempt to develop the various theories behind the major tort headings, but where possible, only to show some cases that are or may become important in this field as it expands beyond its limited present use.

Federal legislation in the most important areas is reviewed with the intention of showing what Acts may be important and their general requirements. In a few places recent case law dealing with specific Acts is included to show, if possible, the judicial attitude in the application of the Acts or regulations made

- Barrister and Solicitor, Atlantic Richfield Canada Limited, Calgary, Alberta. 
thereunder. Many of the Acts included for discussion have been reviewed previously in other editions of this publication as noted, but it is felt desirable, to include these as candidates for the checklist of legislation to be further consulted where impending (or completed) activities may result in environmental legal problems.

Finally, no attempt is made to discuss constitutional problems as yet unresolved in Canada that may have some bearing on the efficacy of certain Federal and Provincial laws, nor is there any specific discussion of the remedy (damages, injunction, or both) that may result from a successful suit by a plaintiff.

It is hoped that the following survey may be of some aid to counsel wishing to get some idea of the range and scope of environmental laws, federal and judgemade, that may have some bearing on the activities of their clients.

\section{FEDERAL LEGISLATION}

\section{Eastern and Western Canada Offshore (Water Legislation)}

The most important Federal statute dealing with pollution caused by ships and vessels is the Canada Shipping Act. ${ }^{1}$ The Act applies to all Canadian territorial waters south of the sixtieth parallel of north latitude and to all Canadian territorial waters north of the sixtieth parallel of north latitude that are not within a shipping safety controlled zone prescribed pursuant to the Arctic Waters Pollution Prevention $\mathrm{Act}^{2}$, and to any fishing zones of Canada prescribed pursuant

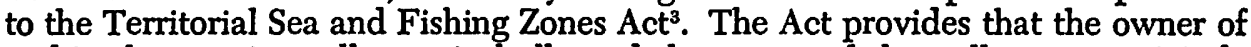
a ship that carries pollutant in bulk, and the owner of the pollutant, are jointly and severally liable for all loss and damage caused by discharge of pollutant from a ship into waters to which the Act applies."

Pollutants, as broadly described, include oil and substances prescribed by the Governor in Council for purposes of this portion of the Act to be a pollutant. ${ }^{5}$

The Oil Pollution Prevention Regulations, $\operatorname{made}^{\mathfrak{b}}$ pursuant to the Act, provide that an oily mixture and a persistent oil mixture are deemed to be pollutants. Pollutants are also described to be any substance that, if added to any waters, would degrade or alter the quality of those waters to an extent that is detrimental to its use, directly or indirectly, by man. ${ }^{8}$

The Act requires that the Master of a ship report the discharge or danger of discharge of any pollutant to the Pollution Prevention Officer or such other person as the Governor in Council may designate. ${ }^{9}$

Ships discharging pollutants in contravention of the Act, or persons who fail to make a report as above or fail to provide evidence of financial responsibility, are guilty of an offence and are liable on summary conviction to a fine not exceeding $\$ 100,000.00 .^{10}$ Additionally, a Minister is given authority to destroy,

1 Canada Shipping Act, R.S.C. 1970, c. S-9; R.S.C. 1970, c. 27, (2nd Supp.).

2 S.C. 1969-70, c. 47; R.S.C. 1970, c. 2 (1st Supp.), proclaimed in force August 7, 1972.

3 R.S.C. 1970 , c. T-7.

4 Supra, n. 1 at s. 734.

Id. at s. $727(1)$.

6 S.O.R./71-495, (1971) 105 Canada Gazette (Part II) 1723, October 13, 1971, amended by S.O.R./73-500, (1973) 107 Canada Gazette (Part II) 2238, September 26, 1973.

IId. at s. 3.

${ }^{8}$ Supra, n. 1 at s. $737(1)$.

$\because$ Id. at s. $738(2)$.

$10 \mathrm{Id}$. at ss. $752,753$. 
if necessary, or otherwise dispose of any ship, its cargo or other material on board a ship, where the Minister has reasonable cause to believe that such a ship is stranded, wrecked, sunk or abandoned, or is discharging or is likely to discharge a pollutant into any waters to which the Act applies.11

Pollution Prevention Officers are given broad powers under the Act. If a Pollution Prevention Officer suspects that any of the regulations or the Act itself has been contravened, he may, with the consent of the Minister, seize the ship and any pollutants that are carried thereon, including such ship to which the Arctic Waters Pollution Prevention Act applies. ${ }^{12}$ Pollution Prevention Officers also have the power to order ships to change course to routes prescribed by them and to order ships near an oil spill to assist in cleaning it up. ${ }^{13}$

The Act imposes joint and several civil liability on the owner of the ship and on the owner of any pollutant for the costs and expenses for the taking of any action by the Government to repair or remedy any condition resulting from the discharge of the pollution that is caused by or is otherwise attributable to that ship and for all actual loss or damage incurred by a Federal or Provincial Government or by any person resulting from the discharge of a pollutant. ${ }^{14}$ The liability of any person to the above named people does not depend upon proof of fault or negligence; ${ }^{15}$ however, there are some exceptions to what is generally known as the strict liability rule which loosely correspond to those contained in the Arctic Waters Pollution Prevention Act and Regulations ${ }^{16}$ and have the following over-simplified classification, viz., force majeur, acts of a third party, negligent acts of the government, and contributory acts of a person damaged thereunder. ${ }^{17}$ The limits of the joint and several liability to the ship and cargo owners are spelled out in the Act and provide that the maximum liability in question shall be determined: ${ }^{18}$

by multiplying two thousand gold francs for each ton of the ship's tonnage but shall not be greater than two hundred and ten thousand gold francs.

The regulations also prohibit the discharge of any oily mixture from any ship in Canadian waters to which the Act applies, except in an emergency, for the purpose of saving life, in case of the loss of a ship or, more importantly, where the discharge of the oily mixture is due to damage or leakage from a ship as a result of stranding, collision or foundering, if all reasonable precautions have been taken to avoid it. ${ }^{19}$

Under these regulations, Canadian ships which carry oil as fuel or cargo must keep records of all losses of oil during loading and unloading of an oil cargo, during exhausting and cleaning of cargo tanks and during other operations, and the regulations further provide that this requirement shall be met by non-Canadian ships in waters to which the Act applies. ${ }^{20}$ However, the regulations do not state the penalties provided for breach of this requirement, thus the Act's penalty provisions must be looked to.

11 Id. at s. 729 .

12 Id. at s. 732 .

${ }^{13}$ Id. at s. 732 (1).

14 Id. at s. 734 .

15 Id. at s. 735 .

16 Supra, n. 2.

17 Supra, n. I at s. $735(1)$.

$18 \mathrm{Id}$. at s. $735(4)$.

10 Supra, n. 6 at s. 6(1).

$20 \mathrm{Id}$. at ss. $28,29$. 
Two other sets of regulations made pursuant to the Canada Shipping Act cover the emission of smoke from ships in Canadian waters to which the Act applies $^{21}$ and the dumping of solid wastes or garbage. ${ }^{22}$

Some recent cases demonstrate the various aspects of strict liability provided for under the Act. In The Dilkara v. The Queen, ${ }^{23}$ the penalty provisions of the Act $^{24}$ were invoked to convict the ship's owners for discharging oil into the waters of Vancouver harbour. The combination of the ship's engineer's miscalculation as to the amount of fuel required and the failure of an electrical alarm device to indicate when the fuel tanks were approximately 75 percent full (to apprise the engineers of any problems in their calculations), resulted in an oil overflow onto the deck and into the water. There was no question that the oil which entered the water was a pollutant within the meaning of the Act and the regulations, but it was contended by the owners of the ship that because a defective alarm failed to sound, the resulting discharge of oil was attributable to the fault of some person not on the ship (presumably looking to s. 735 of the Act without specific reference by the Court). The Court dismissed this contention and held that liability for a discharge of oil was absolute and it was not an answer to say that the discharge would not have occurred but for the fault of persons not on board, or because at an earlier stage a miscalculation as to the quantity of oil to be ordered had occurred. ${ }^{25}$ It was sufficient to prove in a prosecution of a ship for an offence that the act or neglect that constitutes the offence was committed by any person on board the ship. ${ }^{26}$ In so holding, the court in Dilkara approved the decision in Regina v. The Vessel Aran ${ }^{27}$ and words to similar effect: ${ }^{28}$

It follows that. ... all the Crown had to prove was that a discharge of oil or an oily mixture emanated from the ship, and that a person, identified or not, on board caused that discharge and it was not necessary to show what particular conduct or what particular omission of that person resulted in the discharge taking place.

In another recent case, $R$. v. Caird, ${ }^{29}$ involving the oil pollution regulations and the Canada Shipping Act, it was held that where a Master of a ship did not radio a message to Pollution Control Officers as required under the Act and the regulations, the ship owners were liable since mens rea or intent is not an element in the offence of discharging oil, and polluting the water as a result, within the meaning of the Act.

\section{Northern Canada Offshore (Water Legislation)}

One of the most important areas of water legislation as far as the petroleum industry is concerned, and one which will no doubt cause more attention to be directed thereto, is the legislation enacted by the Federal government affecting offshore (and to some extent, onshore) oil operations in the Arctic is the Arctic

21 S.O.R./64-97, (1964) 98 Canada Gazette (Part II) 291, March 25, 1964, amended by S.O.R./66-181, (1966) 100 Canada Gazette (Part II) 461, April 27, 1966 and S.O.R./67-44, (1967) 101 Canada Gazette (Part II) 1682, January 25, 1967.

22 S.O.R./71-654, (1971) Canada Gazette (Part II) 401, April 8, 1964.

28 [1974] 1 W.W.R. 258.

24 Supra, n. 1 at s. 752.

25 Supra, n. 23 at 263.

${ }^{26} \mathrm{Id}$. at 261.

27 (1973) 9 C.C.C. (2d) 179.

$28 \mathrm{Id}$. at 181.

29 (1973) 16 Crim. L.Q. 112. 
Waters Pollution Prevention Act. ${ }^{30}$ There are more extensive reviews of this legislation provided in other literature. ${ }^{31}$

Briefly, the Act covers all territorial waters adjacent to the mainland and the islands of the Canadian arctic within an area enclosed by the sixtieth parallel of north latitude on the southern boundary, the one hundred and forty-first meridian of longitude on the western boundary, and a line measured seaward from the nearest Canadian land a distance of one hundred nautical miles, except between the Canadian islands and Greenland. ${ }^{32}$ While the pollution prevention zones for ships extend 100 miles into the arctic waters, pollution as a result of exploitation of the resources is not so limited but in fact extends to the outer continental shelf. ${ }^{33}$

The extension of jurisdiction for this anti-pollution legislation is questionable. This apparently goes far beyond the recognized international law on this aspect, viz.; the Brussels Convention Relating to Intervention on the High Seas in Cases of Oil Pollution Damage which provides for the above territorial limits ( 100 miles), but does not come into operation until a ship itself is threatened with "material damage" regardless of imminent danger to the coastal zone. ${ }^{34}$. A review of the legal basis of this legislation is beyond the scope of this paper. ${ }^{85}$

The Act covers persons engaged in exploiting natural resources on any land adjacent to the arctic waters, or on any submarine area subject to the Act; persons who carry on any undertaking on the mainland or on the islands of the Canadian arctic which have the effect of depositing waste in the above waters; the owner of any ship that navigates within the arctic waters; and the owners of the cargo on such ship.8

There are penalties arising as a result of depositing "waste", defined" to mean generally any substance added to any waters degrading or altering the quality of those waters to an extent that it is detrimental to its use by man. It also. includes anything that for the purposes of the Canada Water Act is deemed to be waste. ${ }^{38}$

The Governor in Council is authorized to make regulations prescribing the type and quantity of waste for purposes of the Act. ${ }^{30}$ The Arctic Waters Pollution Prevention Regulations ${ }^{40}$ came into effect on the 17th of July, 1972.

Part I does not apply to the deposit of waste by a ship. ${ }^{41}$ Thus any person engaged in non-shipping activities, such as exploring for and developing petroleum, may not deposit industrial wastes except under conditions authorized by the Oil and Gas Production and Conservation Act, the Territorial Lands

30 Supra, n. 2.

32 See, Pharand, The Law of The Sea of The Arctic, (1973) at 224 et seq.; Utton, The Arctic Waters Pollution Prevention Act, and the Right of Self-Protection, (1972) U.B.C. L. Rev. at 221-234; Thompson, The Arctic Environment and Legislation, (1972) 10 Alta. L. Rev. at 431-439.

32 Supra, n. 2 at s. 3(1).

s3 Id. at s. $3(2)$.

34 See, Pharand, supra, n. 31 at 234.

s5 See, Pharand, id. for an exhaustive review at 235-244.

${ }^{36}$ Supra, n. 2 at s. 6.1 .

37 Id. at s. $2(\mathrm{~L})(1)$.

38 R.S.C. 1970, c. C-5 (1st Supp.).

${ }^{39}$ Supra, n. 36 at s. $4(3)$.

40 S.O.R./72-253, (1972) 106 Canada Gazette (Part II) 1033, July 26, 1972.

11 Id. at s. 4 . 
Act, or the Public Lands Act, whichever is applicable.42 The reference to the latter three Acts is provided undoubtedly for some measure of uniformity between certain offshore activities (drilling and exploring) and some of the onshore activities. Domestic waste is permitted if it is similar to that authorized under the Public Health Ordinance of the Northwest Territories or of the Yukon Territories. ${ }^{43}$

The Act imposes civil liability for the deposit of waste by persons described above and such liability is absolute and does not depend upon proof of fault or negligence. ${ }^{44}$ While there is an exception where damage is a result of conduct by a third person, it is provided that indemnification rights are not abridged.45 Since the conduct of a third person includes any wrongful act or omission by that person, for whose wrongful act or omission the defendant is by law responsible, the usual common law rules apply. ${ }^{40}$

Qualifying the limits of liability as described in the Acts, the regulations provide for maximum amounts ${ }^{47}$ depending on the activity giving rise to the liability under the Act. The regulations provide for specified penalties for non-shipping activities including pipelines, ${ }^{48}$ storage of liquid substances, ${ }^{40}$ and most importantly, for industrial operations in the exploring for, developing of or exporting of oil and gas. ${ }^{10}$ The latter provision provides for penalties to a maximum of $\$ 10,000,000$ multiplied by the number of wells from which the deposit of waste originates, but not to exceed $\$ 50,000,000.51$ So far, the regulations do not require evidence of financial responsibility, i.e., insurance for non-shipping activities, but such an obligation is imposed upon ship owners and owners of cargo thereon within the arctic waters. ${ }^{52}$

While ship owners are subject to the same qualifications and requirements under the liability sections, the limitations of liability of a cargo owner had an: exception; viz., that the cargo itself would not be deemed to be waste if it would be permitted to deposit such waste within water quality management zones as enacted under regulations made pursuant to the Canada Water Act. ${ }^{53}$

Although ship and cargo owners are required to have insurance to cover damage due to the depositing of waste on the arctic waters, the insurance policy may contain four exceptions which are outlined in the regulations, ${ }^{54}$ without which the ability to obtain insurance would be highly in doubt. Simply speaking, these exceptions can be described as force majeur, acts of third parties, acts or omissions of the Government responsible for navigational aids, and intentional acts of a ship owner. The first three exceptions are found verbatim in the 1969 Brussels Civil Liability Convention. ${ }^{65}$ These exceptions correspond in some measure to those contained in the Canada Shipping Act. ${ }^{50}$

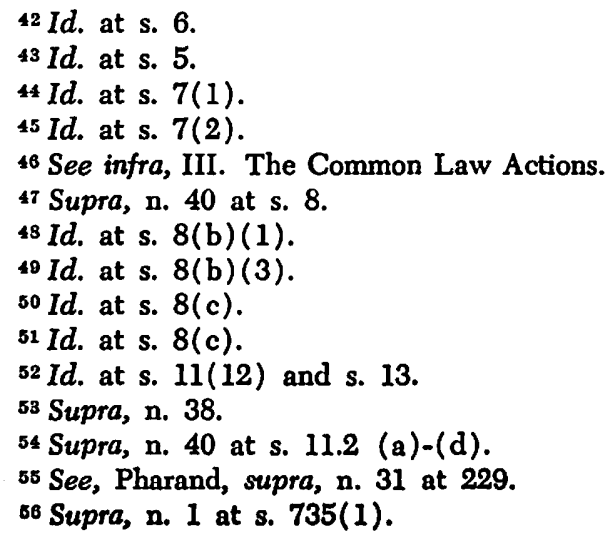


Penalties for deposit of waste by persons or ships in violation of the Act include on summary conviction, a fine not exceeding $\$ 5,000$ in the case of a person, and in the case of a ship, $\$ 100,000$; however, it is deemed that there shall be a separate offence for each day in which the offence is committed or continued.".7 Additional offences are provided for persons, including failure to make reports. ${ }^{58}$ Finally, in a provision similar to that contained in the Canada Shipping Act, ${ }^{59}$ the Act authorizes the Governor in Council or his representative to destroy, if necessary, or otherwise remove, any ship or pollutants thereon where there is a deposit or likelihood of a deposit of waste from a ship.

\section{Northern Canada Mainland (Water Legislation)}

The Northern Inland Waters $A t^{60}$ is intended to provide legislation for water management and development in the Northern Territory, ${ }^{61}$ defined as the Northwest Territories or the Yukon Territories, and in essence is the northern equivalent of the Canada Water Act. ${ }^{62}$ The Act provides for division of the territories into water management areas, as established by regulations. ${ }^{63}$ The Act specifies that no person shall alter or divert the flow or storage of water within a water management area or otherwise use waters within any such area except pursuant to a licence held by him or except as authorized by regulations made pursuant thereto. ${ }^{.4}$ Additionally, no person is allowed to deposit waste of any type in any waters or in any place under conditions where waste may enter such waters. ${ }^{85}$ The above-mentioned provision is mitigated by the exception which allows waste to be deposited according to the conditions of the licence or as authorized by regulations. ${ }^{68}$ The importance of the Act is in the requirement to obtain a licence as aforementioned and in the information which must be supplied pursuant to applications for such licences. ${ }^{67}$ The regulations made pursuant to the Act outline the information required to be supplied. ${ }^{\circ 8}$ This is, in essence, an environmental impact statement similar to that required under NEPA, which has been well publicized. ${ }^{60}$ However, the impact statement under the Northern Inland Waters Act is not as comprehensive and does not require an assessment of the environmental impact or of such construction across the waters, nor of any alternative operation that might result in a lesser environmental impact. ${ }^{70}$ Perhaps with a view toward the impending pipeline crossings and the extensive problems concerned with the numerous possible hearings and the information which would be required for them, the regulations provide that the Controller, which means the Controller of water rights for the Yukon Territory and similarly for the Northwest Territories, may authorize the use of water without a licence if he is satisfied that the proposed use would meet the appropriate requirements of the Act, that the proposed use would not continue

57 Supra, n. 40 at s. 18(2).

58 Id. at s. 19.

so Supra, n. 1 at $729(1)$.

${ }^{60}$ R.S.C. 1970 , c. 28 (1st Supp.).

61 Id. at s. $2.1(\mathrm{~g})$.

62 Supra, n. 38.

o3 Supra, n. 60 at s. 26 (d).

64 Id. at s. 3.2 .

${ }^{65} I d$. at s. $6(1)$.

${ }^{60} I d$. at s. $6(1)$.

${ }^{67} I d$. at s. 11(1) and s. 11(2).

68 See supra, n. 60 at s. 8.

60 1959, 83 Stat. 852; 42 U.S.C. 4321 (1970).

70 For a review, see White, United States Environmental Laws and Exploration and Production Operations, this issue. 
for a period of more than ninety days and that the proposed use consists mainly in the laying, placing, building, or erecting, of any structure, device, or contrivance in, over, under, or upon any waters. ${ }^{71}$ Since no licence would be required in this particular case, no impact statement would have to be submitted. While this provision in the regulations does not require the obtaining of a licence and supplying impact statement, nevertheless, the Controller would have to be satisfied that the company making application thereunder would subscribe to the provisions of the Act, wherein it is required that any disturbance or deposit of waste or use of the water which is detrimental to the original condition of the waters shall be rectified so that water quality standards shall be maintained. ${ }^{72}$

The Act further provides that a public hearing shall be held by a Board in connection with each application for a licence or for a renewal of a licence. ${ }^{73}$ However, this hearing can be dispensed with if the applicant consents in writing to the disposition of the matter without a public hearing and there is no notice received by the Board, within ten days after publication of the notice of a public hearing, that any person intends to appear and make representations in connection with the matter. ${ }^{74}$ It has been argued that any arterial road or pipeline crossing would involve at least temporary obstructions during pier or support construction and therefore, such an obstruction would constitute use of water under the Act. ${ }^{75}$

Applications for pipeline crossing may be made under the Act, ${ }^{76}$ however, a public hearing would still be required. Failure to obtain a licence for the deposit of waste of any type in any waters covered under the Act or exceeding the quantity of water authorized within any particular licence is deemed to be an offence and an offender liable, on summary conviction, to a fine not exceeding $\$ 5,000 .{ }^{77}$ Where such an offence is committed on more than one day, it is deemed to be a separate offence for each day in which the offence is committed or continued..$^{78}$

While it is sufficient proof of the offence to establish that it was committed by an employee or agent of the accused, whether or not the employee or agent is identified, the accused, with obvious reference to the situation of employer and independent contractor common in the north, is ostensibly not subject to prosecution hereunder if he establishes that the offence was committed without his knowledge or consent, and that he had exercised all due diligence to prevent its commission. ${ }^{79}$ This section is identical, for all practical purposes, to a provision in the Fisheries Act. ${ }^{80}$ For a defence based on due diligence, a defendant may require rather extensive evidence that he effectively communicated proper instructions to employees, etc., which, if followed, would probably not lead to an offence under the Act. ${ }^{81}$ Furthermore, a court may impose a restraining order to terminate the offensive activity. ${ }^{82}$ Finally, the Act provides that there

71 Supra, n. 40 at s. 11.

72 Supra, n. 60 at s. $10(1)$.

${ }^{73} \mathrm{Id}$. at s. $15(1)$.

74 Id. at s. $15(2)$.

73 Canadian Arctic Resources Committee, Arctic Alternatives, (1973) at 342.

${ }^{76}$ Supra, n. 60 at s. $24(1)$.

77 Id. at s. 32.

78 Id. at s. $32(2)$.

79 Id. at s. 35 .

80 R.S.C. 1970 , c. F-14, as amended by R.S.C. 1970 , c. 17 (1st Supp.) at s. $33(8)$.

81 Infra, n. 109, for a case decided on the identical provision under the Fisheries Act.

82 Supra, n. 60 at s. 34. 
shall be no defence to a civil claim based on anything contained in the Act, the regulations or in a licence issued pursuant thereto, if there is loss or damage sustained by any person by reason of any construction of any work forming part of an appurtenant undertaking or the operation thereof. ${ }^{83}$

There are no civil remedies provided for under the Act such as there are in the Arctic Waters Pollution Prevention Act ${ }^{84}$ and the Canada Shipping Act. ${ }^{85}$ Overall, the Act is consistent with other Federal legislation covering the Provincial areas, but is more extensive than its southern counterpart, the Canada Water Act (outlined in the next section). The penalty and proof provisions are similar to the Fisheries Act which apply to all waters throughout Canada, including the northern areas. ${ }^{86}$

\section{Southern Canada Mainland (Water Legislation)}

\section{(a) Canada Water Act}

The Canada Water Act, ${ }^{87}$ passed by the Federal Parliament in 1970, is part of the Government's scheme to regulate the Canadian environment on a national scale through co-operation of the Provincial governments and to set nation-wide standards of environmental quality and together with its counterpart, the Northern Inland Waters Act, ${ }^{88}$ covers all waters located inland. The Act empowers the Minister (Energy, Mines and Resources), with respect to any water wherein there is a significant national interest, to enter into agreements with one or more Provincial governments having an interest in the resource management of those waters. ${ }^{89}$

The Act authorizes the Department to undertake water resource management programs directly where Federal waters are involved, or in connection with inter-jurisdictional waters and any international or boundary waters wherein there is a significant national interest.90 With respect to the latter two, i.e., interjurisdictional and international waters, there are obviously constitutional questions involved. ${ }^{11}$ So far, the Act has only been used to pass regulations limiting phosphorous concentration in cleaning agents and to do studies of water basins. ${ }^{92}$

\section{(b) The Fisheries Act}

An important Federal statute dealing with water pollution is the Fisheries Act, ${ }^{93}$ which applies to virtually all Canadian waters and which prohibits the discharge of a wide variety of so-called pollutants into those waters. The Fisheries Act provides that no person shall deposit a deleterious substance of any type in water frequented by fish, or in any place under any conditions

83 Id. at s. 25.

84 Supra, n. 2.

85 Supra, n. 1.

86 Infra, text accompanying n. 93 et seq.

87 Supra, n. 38.

88 Supra, n. 60.

89 Supra, n. 38.

$90 I d$. at s. $5(1)$ and s. 11 .

91 For a review of possible issues, see, Gibson, Constitutional Jurisdiction Over Environmental Management in Canada, (1973) 23 U.T.L.J. 54.

92 Phosphorus Concentration Control Regulations, S.O.R./70-354, (1970) 104 Canada Gazette (Part II) 863, August 26, 1970 and S.O.R./72-416, (1972) 106 Canada Gazette (Part II) 1820, October 25, 1972.

93 Supra, n. 80. 
where such deleterious substance, or any other deleterious substance that results from the deposit of such deleterious substance, may enter any such water. ${ }^{94}$

For the purposes of the Act, deleterious substances have been defined ${ }^{0 s}$ in terms that are consistent with, if not identical to, the definition of waste under the Arctic Water Pollution Prevention Act, ${ }^{06}$ the Northern Inland Waters Act, ${ }^{07}$ and the Canada Water Act. ${ }^{98}$

The Act also prohibits the dumping overboard of specific materials harmful to fish into any river, harbour, or roadstead or in any water where fishing is carried on, or upon or along shorelines below the high-water mark. ${ }^{99}$ There is the familiar maximum fine for offences under the Act, which is $\$ 5,000$ for each separate offence and for each day on which the offence is committed or continued. ${ }^{100}$

Under the new amendment, the Act is made binding on the Federal government as well as the Provincial governments, although the latter may prove an interesting exercise. ${ }^{101}$ Also under the amendment, the Minister has discretion to require any person who proposes to undertake any alteration, etc., the operation of which is likely to result in the deposit of a deleterious substance of any type in water frequented by fish, to provide him with a copy of such plans and specifications relating thereto as will enable him to determine whether the deposit of such substances would constitute an offence within the meaning of the Act. ${ }^{102}$ Such person must also provide a broad variety of information, including samples of any materials used such as would enable the Minister to cause an analysis to be made of the nature, quantity and quality of any effluent resulting from the operation, ${ }^{103}$ and, if the Minister so decides, he has the authorization and the power, after a review, to require such modifications in those plans and specifications as he considers to be necessary or to prohibit the carrying out of the construction, alteration or extension. ${ }^{104}$

\section{(i) Regulations}

Of the two sets of regulations promulgated under the Fisheries Act, the Penalties and Forfeitures Proceeds Regulations ${ }^{105}$ may prove important. Under the regulations there is a rather unique provision calling for the payment of half the fine to a private citizen where prosecution was commenced as a result of a complaint made or an information laid by such citizen and has resulted in a fine, and additionally, half of any proceeds recovered from the sale of any equipment, seized and sold by the Government which was used in the violation ${ }^{106}$ The Act also encourages Fisheries Officers or guardians employed by the Department of the Environment by providing them with the same incentives. ${ }^{107}$

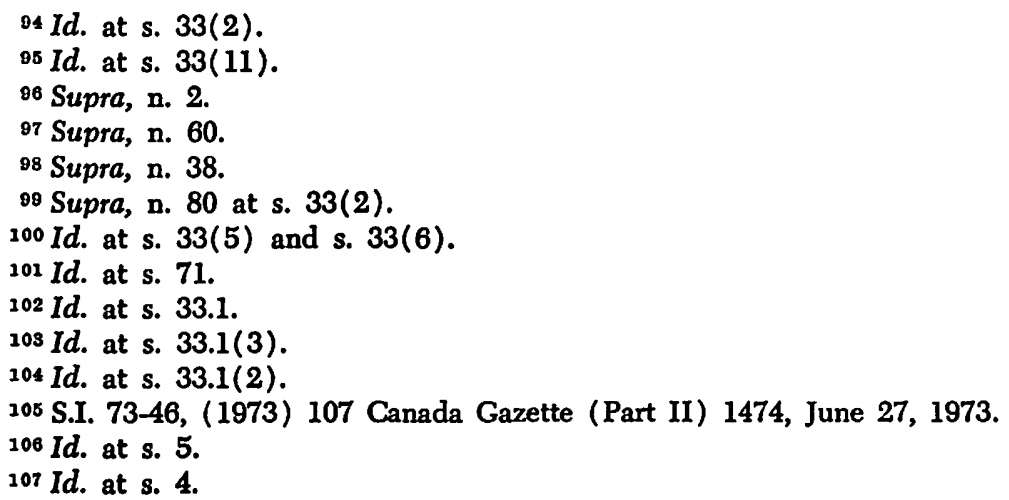


(ii) Cases

This Act is among the few having any judicial activity insofar as the pollution provisions are concerned, and therefore some recent cases may be helpful in determining how some of the sections of the Act discussed above have been interpreted.

The defence of "due diligence" under the Act ${ }^{108}$ was held not maintainable in R. v. MacMillan Bloedell Industries, Ltd. ${ }^{109}$ since the defendant company had not successfully communicated adequate instructions to employees undertaking a gravel washing operation.

Besides the necessity of showing that a substance has been deposited in waters frequented by fish, it must be proved that such substances are actually harmful or deleterious to fish. Where only fish eggs are concerned, there is apparently no violation of the Act. ${ }^{110}$

In the recent case of $R$. v. Churchill Copper Corporation Ltd., ${ }^{111}$ it was held that this section provided strict liability (criminal) without the showing of mens rea and therefore the defendant was charged with depositing deleterious substances in waters frequented by fish.

\section{(c) Navigable Waters Act}

This $\operatorname{Act}^{112}$ is of possible minor consequence in that its enforcement has been less than aggressive. The Act does provide that no work shall be built or placed in, upon, over, under, through or across any navigable water unless the work, the site, and the plans have been approved by the Minister and the construction has commenced within six months and has been completed within three years of the approval referred to above. ${ }^{113}$

The Act provides that the Minister has discretion, except in respect of certain works and undertakings, to exempt the application of the provisions of this Act to any of certain kinds of projects which would not interfere substantially with navigation.114 The Act is administered by the Department of Transport and licences must be obtained therefrom. Although the Minister has the authority to remove, alter, destroy or otherwise dispose of any works and to stay any person from proceeding with the construction of the work if such project has not been approved prior to the commencement, the Minister may nevertheless approve of the work, the plans and the site thereof after construction has commenced since approval is retroactive. ${ }^{115}$ However, if the Act were applied as a means of water resource management, rather than for navigable aspects, there may well be serious questions as to its validity. ${ }^{116}$

(d) Other Acts

Another Act which may have some pertinence hereto is the Migratory Birds Convention Act. ${ }^{117}$ The Act is administered by the Minister of Indian Affairs and Northern Development. Under regulations made pursuant to the Act, it is

${ }^{108} \mathrm{Id}$. at $\mathrm{s.} 33(8)$.

109 (1974) 13 C.C.C. (2d) 459.

110 R. v. Stearns-Roger Co. (1973) 12 C.C.C. (2d) 260, reversing [1974] 2 W.W.R. 669.

111 [197] 4 W.W.R. 481.

112 R.S.C. 1970 , c. N-19.

113 Id. at s. $5(1)$.

114 Id. at s. $5(2)$.

$115 \mathrm{Id}$. at s. 6(4).

116 See Gibson, supra, n. 91 at 73.

117 R.S.C. 1970 , c. M-12. 
provided that no person shall cause the entrance of oil, oil wastes or substances harmful to migratory birds into waters, or upon the ice covering such waters.118 The penalties provide for a maximum fine of $\$ 300$ or imprisonment for a term not exceeding six months, or both. ${ }^{119}$

The Act further provides that one-half of every penalty imposed and collected under this Act or any regulations made pursuant thereto, where "any person who is not a Game Officer is the prosecutor", shall be paid to such person on whose evidence that conviction is made. ${ }^{120}$

There are various other pieces of legislation aimed at pollution from ships, obstructions, caused by other industries, which hinder transportation, and for land use planning on waterfronts which to date have not been vigorously applied, and for purposes of this paper shall not be reviewed. ${ }^{121}$

\section{Northern Canada Mainland (Land)}

While the waters of the Arctic, on both land and offshore, are extensively covered by legislation covering all phases and activities that would significantly affect the quality of the water, the Arctic land regulations are not so complete or extensive. This is perhaps because any deleterious effects of various actions may not readily be assessed or are not so visibly striking, at least as compared to oil spills on water. Those various activities, excluding those which would affect the rivers and lakes and the Arctic offshore, would be in large part drilling operations covered by the Canada Oil and Gas Drilling and Production Regulations, ${ }^{122}$ made pursuant to the Territorial Lands Act. ${ }^{123}$ The geophysical aspect of various petroleum activities would be covered by the Territorial Land Use Regulations $^{124}$ and the Oil and Gas Production and Conservation Act, ${ }^{125}$ for which there have been no regulations made as yet. The activities of various aspects of operations in transportation of men and equipment, and the breaking of trails, etc. to and from various sites would be covered in part by the Canadian Oil and Gas Production and Conservation Act, ${ }^{120}$ and the Territorial Land Use Regulations. ${ }^{127}$

The Territorial Land Use Regulations define land use operations generally as activities involving the use of roads, trails, rights of way and campsites.128 Most importantly, the regulations do not apply to lands disposed of by the Minister, which probably exempts drilling and well sites. ${ }^{129}$

Part One of the regulations provides that certain types of land use operations may not be carried out except with the prior written authority of the Engineer, e.g., excavating territorial land within 300 feet of any stream at a point that is

118 S.O.R./66-361, (1966) 100 Canada Gazette (Part II) 1033, August 24, 1966 at s. 51 .

119 Supra, n. 118 at s. $12(1)$.

$120 \mathrm{Id}$. at s. $12(2)$.

121 For example, see Government Harbours and Piers Act, R.S.C. 1970, c. G-9; National

Harbours Board Act, R.S.C. 1970, c. N-6; Harbours Commission Act, R.S.C. 1970, c. $\mathrm{H}-1$.

122 S.O.R./61-253, (1961) 95 Canada Gazette (Part II) 805, June 28, 1961.

123 R.S.C. 1970 , c. T-6.

124 S.O.R./71-580, (1971) 105 Canada Gazette (Part II) 1908, November 24, 1971.

125 R.S.C. 1970 , c. $0-4$.

126 Id.

127 Supra, n. 124.

128 Id. at s. 2.

120 Id. at s. 3(b). 
below the normal highwater mark of that stream, depositing on the bed of any stream any excavated material, ${ }^{130}$ leaving various and sundry debris or material, or clearing lands, constructing ditches, or even leaving roads damaged or rutted after constructing crossings over any highways. ${ }^{131}$ An operator must use any existing lines, trails, or rights of way where possible or otherwise he must obtain the prior written consent of the Engineer to clear a line, trail, or right of way, and generally he must provide for good management with respect to the aforementioned activities. ${ }^{132}$ Insofar as water crossings are concerned, the Act makes clear that the Fisheries Act $^{133}$ applies so that no operator is permitted to deposit any material or debris in contravention thereof. ${ }^{134}$

Part Two of the Regulations dealing with land management zones requires a permit to be obtained ${ }^{135}$ prior to conducting any land use operation. An applicant must submit certain information including the types of land proposed to be used, the quantity, the location of various existing lines, trails and rights of way, and buildings, campsites, bridges, dams, and ditches, railroads and highways that may be affected by the land use operation. ${ }^{130}$ Before issuing any land use permit, the Engineer may order an inspection of the land proposed to be used thereunder ${ }^{137}$ and may issue a permit subject to various conditions, including highly detailed measures for the protection of the land or wildlife habitat and such other matters, not inconsistent with the regulations, as the Engineer thinks necessary for the protection of the ecological balance or physical characteristics of the land management zone. ${ }^{138}$ Any land use permit issued may require a security deposit, to be refunded when the Minister is satisfied that the operations have been completed and comply with the terms and conditions of the land use permit and the regulations contained therein. ${ }^{130}$ There are however, no civil liability provisions included under the Act.

One case may be of some interest to show how the regulations are applied in certain circumstances and the judicial attitude in that respect. The defendant in Her Majesty the Queen v. Kenasten Drilling (Arctic) Limited, , $^{140}$ was held to be in violation of the Territorial Land Use Regulations for operations conducted in a land management zone without a land use permit as required by s. 17(d). A Nodwell tractor containing a seismic drill operated by the defendant had moved some 67 miles across the Arctic tundra without the required permit. A parallel ice road, not requiring a permit, apparently was too unsafe for use at that time of the year (May). The Magistrates Court had levied a $\$ 100$ fine for the above breach (under s. 3.3 of the Territorial Land Act) but the Appeals Court increased that fine to $\$ 2,000$ as a discouragement of further violations. Apparently it was not necessary to prove that damage had actually occurred but the court's attitude is worth noting: ${ }^{141}$

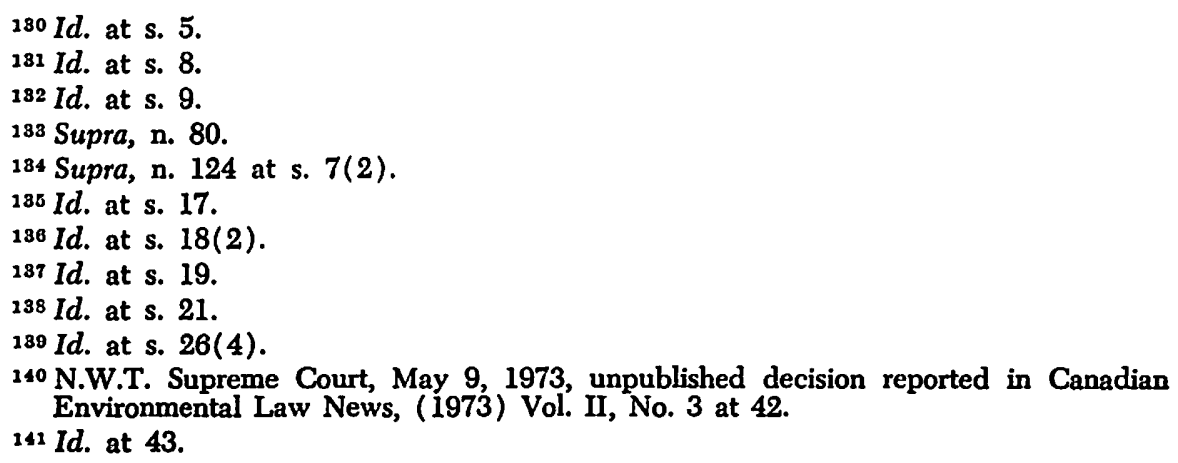


It may well be that in the present case no actual damage took place. But surely the test to apply in approaching the question of sentence should be less a concern of what the damage was but more a concern of what the damage might have been.

The Canada Oil and Gas Drilling and Production Regulations ${ }^{142}$ are not really intended to cover the environmental aspects of activities such as exploration and drilling of wells and operations carried out in producing and transporting oil and gas, although there are the usual sections requiring the restoration of the surface after abandonment ${ }^{143}$ and the disposal of excavation material and salt water. ${ }^{144}$

The Canada Oil and Gas Land Regulations ${ }^{145}$ govern the issuance of permits and leases for petroleum and natural gas in the Canadian north and in the western and eastern coastal offshore regions. Although the leases could be issued subject to conditions contained therein, there are no environmental provisions included in the Act. However, it has become the practice by the Committee to issue leases in the Beaufort Sea, subject to environmental impact studies being undertaken prior to any drilling or production. In this regard, a group of member companies, called the Arctic Petroleum Operators' Association (APOA), which holds permits to explore for oil and gas in the Beaufort Sea, is currently undertaking environmental studies relating to the impact of the proposed activities. The Minister for Indian Affairs and Northern Development has publicly stated that no drilling will be allowed before the summer of 1976 in order to assess the environmental impact prior to actual commencement.

The Oil and Gas Production Conservation Act ${ }^{146}$ contemplates enactment of environmental regulations which are still in the process of preparation by the Federal government, and will no doubt have provisions similar to other legislation covering the Arctic waters. ${ }^{147}$ The Act provides for regulations prescribing the measures necessary to prevent the pollution of air, land or water as a result of the exploration and drilling for and the production, storage, transportation, distribution, measurement, processing or handling of any oil or gas, including generally, injection of substances into underground formations. ${ }^{148}$

6. Air

Most of the pollution laws dealing with the quality of air are the subject of extensive Provincial concern. However, there is one Federal statute enacted which has the potential of defining air quality standards throughout all of Canada but so far has not been actively enforced since no regulations have yet been passed. The Clean Air Act ${ }^{149}$ in part gives the Federal government authority to set national air quality objectives and national emission standards where there is a significant danger to health ${ }^{\mathbf{1 5 0}}$ and provides for Provincial-Federal agreements on national ambient air quality objectives, ${ }^{151}$ but no legally binding standards have been set, nor have any regulations been made to enforce the objectives of the Act. It is generally assumed (by the Provinces) that the Federal

142 Supra, n. 122.

143 Id. at s. 16.

144 Id. at s. 31 and s. 32.

145 Supra, n. 122.

146 Supra, n. 125.

147 Arctic Waters Pollution Prevention Act, supra, n. 1; Northern Inland Waters Act, supra, n. 60.

148 Supra, n. 125 at s. $12(\mathrm{q})$.

140 S.C. $1970-71-72$, c. 47.

$150 \mathrm{Id}$. at s. 7.

151 Id. at s. 19. 
government will co-operate with Provincial governments prior to any unilateral enforcement of the Act. Therefore, legislation in each province must be looked to if problems arise. ${ }^{152}$

\section{THE COMMON LAW ACTIONS}

There are a number of common law rights or remedies which may be considered as possible causes of action or liability for the protection of the environment. Papers in previous years for the Canadian Petroleum Law Foundation more than ably explore the possible bases of liability for various aspects of the petroleum industry's activities which may presently be considered as belonging in part within the heading of Environmental Law, viz., oil spills and blowouts (onshore or offshore), in northern Canada affecting the liability of an owner due to his employee or to an independent contractor, ${ }^{153}$ air pollution by natural gas processing plants, ${ }^{154}$ damages from seismic explosions, ${ }^{155}$ and damages from waterflooding schemes. ${ }^{150}$ The principles underlying the above are applicable, of course, to any situation within Canada where the common law is applicable.

The common law remedies will only briefly be covered here in order to show some recent cases which may have a bearing on the direction of Canadian law in this respect. These cases are not necessarily restricted to petroleum industry activity since such cases presently are few in any event.

One of the problems in reviewing various common law rights and remedies in the context of environmental litigation is the apparent confusion that exists within the Courts as to the definition and description of various torts that may be applicable. One commentator aptly summed it up as follows: ${ }^{157}$

When we are variously informed that liability in nuisance is strict, that proof of negligence is not required in nuisance, that nuisance and negligence are assimilated, that fault is nearly always present in nuisance, that foreseeability is the test for remoteness in nuisance, and that Rylands v. Fletcher is analagous to, but different from nuisance, counsel might be forgiven for concluding that he is on his own.

With this caveat in mind, it is the author's intention only to present some cases which may arguably be included within that amorphous field of law popularly referred to as Environmental Law. No warranty is given as to the correctness of including any specific cases as being necessarily representative of a particular field. However, it is believed that these cases may be of some help to companies or individuals faced with the prospect of environmental litigation or as the basis for reviewing or further researching suggested environmental problems as a preface to impending company activity.

Traditional common law actions covering various aspects of pollution control or liability may result in recovery of damages or in an injunction, the

152 For an earlier review of some issues that may arise in this field, see Curran, Tort Liability Respecting Natural Gas Plants, (1966) 5 Alta. L. Rev. 1 at 14; see also, the Provincial pollution legislation as outlined by P. Schmidt as a part of this issue's presentation.

${ }^{158}$ Lewis, Legal Liability in the Canadian Arctic Relating to Oil Spills and Blowouts, (1972) 10 Alta. L. Rev. 440.

154 Supra, n. 152.

155 Geophysical Damage to Property and Related Claims, (1966) 5 Alta. L. Rev. 29.

166 Tort Liability in Waterflood Operations, (1966) 5 Alta. L. Rev. 53.

157 McClaren, The Common Law Nuisance Actions and the Environmental Battle Well-Tempered Swords or Broken Reeds, (1972) 10 Osgoode L.J. 505 at 520. 
latter being used in the usual case of abating a continuing nuisance. As previously stated, ${ }^{158}$ these actions include strict liability, nuisance, trespass and negligence. In addition to the above, which are limited mainly to problems arising in the arctic, there is one other cause of action in the Provinces which may be applicable under certain circumstances, viz., riparian rights. All of these will be covered briefly.

\section{Strict Liability}

The modern rule of strict liability in Canada had its birth in the English case of Rylands v. Fletcher, ${ }^{159}$ wherein it was enunciated by Blackburn J. that: ${ }^{160}$

a person who for his own purposes brings on his land and collects and keeps there anything likely to do mischief if it escapes, must keep it at his peril, and, if he does not do so, is prima facie answerable for all the damage which is the natural consequence of its escape.

Over a period of years the rule has been applied mainly in those instances involving isolated escapes of dangerous things accumulated on the land ${ }^{161}$ in contradistinction to nuisance actions, usually brought for a continuing interference with the use and enjoyment of one's land. Apparently it is not necessary that the mischievous substance cause damage or harm on the land of the plaintiff in order for liability to attach, but rather that the defendant will be liable for all damage caused by the mere escape of the mischievous substance from his land. ${ }^{162}$ "Mischievous substances" has been interpreted to mean objects that are not likely to escape, but which would entail exceptional peril to others. ${ }^{163}$ Such objects include water, electricity, gas, oil, fire and explosives. ${ }^{164}$ The criterion has been stated in terms of "some special use" bringing with it increased danger to others and not merely the ordinary use of the land or such a use as is proper for the general benefit of the community. ${ }^{165}$

There are widespread and divergent opinions on the applicability of the rule. It has been suggested that an argument may be made that the rule may not apply to the "escape" of noxious fumes from gas processing plants located in some gas fields, ${ }^{100}$ that it would probably apply in many instances to damage caused by blasting in geophysical operations, ${ }^{107}$ and that waterflooding for oil production purposes is a "non-natural" use of the land but may well fall within the statutory authorization defence to the rule. ${ }^{108}$

The case of Christa v. Marshall, ${ }^{160}$ wherein it was held that the drilling of artesian wells resulting in flooding of defendant's land was subject to the rule, would seem to suggest that anyone drilling oil and gas wells resulting in damage to another's land would be held strictly liable except for the defence of statutory authorization. With respect to this latter defence, it is unclear

158 See Lewis, supra, n. 153.

150 (1866) L.R. 1 Ex. 265, aff'd. (1868) L.R. 3 H.L. 330, hereinafter called Rylands v. Fletcher.

160 (1866) L.R. 1 Ex. 265 at 279-280.

101 McLaren, "Nuisance in Canada", Studies in Canadian Tort Law, (1968) at 365.

102 Halsey v. Esso Petroleum Co. Ltd. [1961] 2 All E.R. 145 (Q.B.).

108 Fleming, Law of Torts, (1971) 4th ed. at 284.

164 Id. at 285.

165 Richards v. Lothian [1913] A.C. 263 at 280.

166 Supra, n. 152.

167 Supra, n. 155.

168 Supra, n. 156.

169 [1945] 2 W.W.R. 44. 
whether statutory schemes authorizing the operations are permissive (usually no defence) or mandatory (usually a good defence)..$^{170}$

A combination of special, non-natural uses of the land with objects not ordinarily hazardous or dangerous may fall within the rule. In a recent Alberta case, Heintzmen and Co., Ltd. v. Hashman Construction Limited, ${ }^{171}$ it was found that the construction of a building was a "special use" and temporarily the subject of a special risk.172 Therefore, the escape or "leaving" of either debris or fabric, accumulating on defendant's land without adequate restriction to prevent such escape, placed the defendant in the position of strict liability under the rule. ${ }^{173}$ The case also held that the defendant would be liable under the principles of nuisance as well.

In the more traditional sense, there are a number of recognized and historically developed defences which have some correlation to the exceptions contained in the main strict liability statutes (Arctic Waters Pollution Prevention Act $^{174}$ and Canada Shipping Act ${ }^{175}$ ) enacted by the Federal government, namely, force majeur, intentional acts of a third party and statutory authority in addition to the consent or default of the plaintiff. ${ }^{176}$

\section{Nuisance}

The common law has evolved two forms of action, both entitled nuisance, i.e., private nuisance and public nuisance, that have distinct differences. Private nuisance has always been regarded as interference with the beneficial use of another's land, as contrasted with public nuisance, which generally gives rise to a cause of action for damages to a member of the general public sustaining personal injury or other loss in the coverage of rights common to all.177

While the tort of public nuisance would seem to have spawned many environmental suits involving various aspects of the petroleum industry's activities, especially transportation, recent environmental litigation suggests that there are severe limitations to such a cause of action, namely, where the plaintiff is a private individual, he must prove that he has suffered special damage beyond that suffered by a significant class of the public. ${ }^{178}$ Thus in the recent case of Hickey v. Electric Reduction Co. of Canada, ${ }^{170}$ it was found by the court that fishermen using the harbours of Placentia Bay were not such a class of the public suffering special damage from pollution by defendant's plant. Since the right to fish was a public right, it was encumbent on the plaintiff to show that the damage suffered was different in kind, rather than in degree, than that suffered by the public at large. Since the whole public, in this case all the fishermen using the harbours, suffered equally, a private action for public nuisance could not stand. The reasoning behind this is the court's reluctance to allow the multiplicity of suits, which might result, if many members of the public sued, without proof of actual damage. ${ }^{180}$

170 See infra, n. 198 and text.

171 [1973] 1 W.W.R. 202.

172 Id. at 206.

173 Id. at 208.

174 Supra, n. 29.

175 Supra, n. 1.

${ }_{170}$ See Fleming, supra, n. 163 at 289-293.

177 Id. at 340.

178 Fillion v. N. B. International Paper Co. [1934] 3 D.L.R. 22 (N.B.C.A.) at 26.

179 (1972) 21 D.L.R. (3d) 368.

180 Walsh v. Ervin (1952) V.L.R. 261 (A.C. Vict.) at 268. 
It is proper, of course, in the latter case, that the Attorney General for the Province or for the Federal government bring a suit to enjoin the public nuisance. ${ }^{181}$

It is even possible for a private individual to persuade the appropriate Attorney General to bring a suit as guardian of the public interest, and be included therein as a relator with the Attorney General perhaps as only a nominal plaintiff, but this is rarely used and the discretionary power of the Attorney General is absolute. ${ }^{182}$ Class actions are also not maintainable for nuisance, ${ }^{183}$ thereby significantly reducing the number of potential suits.

Whereas public nuisance has not presented any major developments in the field of anti-pollution litigation, mainly because of the problem of restrictions on standing to sue (plaintiff required to prove special damage), private nuisance actions are likely to abound in the more populated areas. There are two aspects to this cause of action: the interference with the use and enjoyment of someone's property, such as by smoke, smell, noise, etc., and the actual physical damaging of another's property. In the latter case, the plaintiff is not required to prove fault in the traditional sense, ${ }^{184}$ but only that the plaintiff was damaged by some act of the defendant which could properly be called a nuisance, eg., cars stored on plaintiff's property damaged by particulate matter emanating from defendant's foundry operation.

Where the complaint lies for unreasonable interference with the use and enjoyment of one's land, there is a balancing of factors, such as the utility of defendant's conduct on his land against the damage incurred by plaintiff, ${ }^{185}$ including the sensitivity of the plaintiff, the character of the locale, and the duration of such interference.

In a very recent case that involved some of the issues raised above and which might forbode the direction of nuisance actions, the Supreme Court of Canada ${ }^{186}$ awarded an injunction to plaintiff on the basis of abating noise created by shotguns firing on defendant neighbour's game farm. Defendant operated a commercial game farm on his land and was actually located there prior to the plaintiff. The noise was found by the Trial Court to be objectionable and irritable, while the Supreme Court stated it to be "disturbing" (p. 94). The Supreme Court also made it clear that while the injunction, as modified by the Appeals Court, would eliminate the constant risk of physical invasion of plaintiff's land by shot pellets from the hunter's gun (by reduction of the allowable shooting area), it would not stop the recurring, continuing noise associated with the shooting and thus reinstated the trial Judge's permanent injunction against all shooting on defendant's land. Unfortunately, there were no cases cited for the above proposition. It cannot be really known what direction the courts will take as a result of this case.

In another recent case, the Manitoba Court of Appeal in Connery v. Government of Manitoba ${ }^{187}$ held that where defendant, a government body, built a floodway in order to divert the Red River waters, which resulted in polluting

181 St. Lawrence Rendering Co. v. Cornwall [1951] O.R. 669 at 673.

182 Grant v. St. Lawrence Seaway [1960] O.R. 298 (C.A.).

183 Supra, n. 181.

184 Russell Transportation Ltd. v. Ontario Malleable Iron [1952] O.R. 621 (H.C.).

185 McLaren, "The Law of Torts and Pollution", Law Society of Upper Canada Special Lectures, (1973) at 317.

186 Easter v. Reynes [1973] S.C.R. 85.

187 [1971] 4 W.W.R. 156. 
plaintiff's wells by the increased salinity, it was not necessary to find that defendant had not been negligent, quoting from the earlier case of Portage La Prairie v. B. C. Pea Growers Ltd. ${ }^{188}$ This was a case which involved direct damage to plaintiff's business (growing plants) by the altered quality of water. As stated by the judge: ${ }^{180}$

in my view, it is nothing more than semantics to try to confuse the words 'contamination, pollution and poisoning by the changing the nature of. In this particular case the quality of the water was changed. That is pollution.

Liability to the defendant, however, did not extend to cover plaintiff's heart attack resulting from the loss of business.

\section{Riparian Rights}

Another action which is similar but not identical to the private nuisance actions is the interference with an owner's riparian rights. These rights are not proprietary in the sense that one actually owns the waters of the lakes, rivers and streams appurtenant to his property but rather the right is to utilize such water, (in certain circumstances for domestic purposes) and to receive the water with no sensible diminution in quality or quantity. ${ }^{190}$ The Plaintiff does not have to prove damage since the introduction of the pollutant is an actionable wrong even without proof of damage. ${ }^{191}$

The most important aspect of this cause of action, insofar as this paper is concerned, would of course be the question relating to quality of the water and probably the two most recent important Canadian cases in that regard are McKie v. K.V.P. Co. $L t d{ }^{102}$ wherein an injunction was granted by the Court to abate the continuing emission of pollutants by defendant company's paper mill into a river, and Stephens v. Richmond Hill, ${ }^{103}$ wherein the Court granted an injunction for abating the operation of a municipal sewage plant which was contaminating waters running through plaintiff's lands. In $M c K i e$, in addition to the lack of necessity for proving damage to plaintiff's use and enjoyment of the water in a natural state, the court also held that it was unnecessary and irrelevant to show the importance of defendant's business to the community or its economic necessities in order to succeed in the action.

In two cases involving the release of sewage effluent by municipalities into waters, thereby resulting in deterioration of the quality of plaintiff's water, the courts granted an injunction to stop operation by the defendant to the extent that it affected the claiming riparian owners, ${ }^{194}$ notwithstanding the defence of statutory authority by defendants in both cases. ${ }^{195}$ In the latter case, damages were assessed in addition to the injunction (which was stayed for one year).

In an earlier case which set the foundation for later cases in the qualitative aspect of infringement of riparian rights, the Supreme Court of Canada, in Groat

188 (1964) 50 W.W.R. 415, aff'd. (1966) 54 W.W.R. 477.

180 Supra, n. 187 at 160.

100 Young \& Co. v. Barkier Distillery Co. [1893] A.C. 691 (H.L.).

101 Halsbury, Laws of England, 3rd ed., Vol. 39 at 722; McKie et al. v. K.V.P. Co. Ltd.

[1948] 3 D.L.R. 201 (H.C.), aff'd [1949] S.C.R. 698; Hawrish v. Holden (Village)

(1960) 32 W.W.R. 491.

102 Id.

193 (1956) 1 D.L.R. (2d) 569.

194 Supra, n. 191.

105 Infra, n. 198. 
v. Edmonton, ${ }^{198}$ a case involving the pollution of plaintiff's waters by the City of Edmonton, stated: ${ }^{197}$

The right of a riparian proprietor to drain his land into a natural stream is an undoubted common law right, but it may not be exercised to the injury or damage of the riparian proprietor below, and it can afford no defence to an action for polluting the water in a stream. Pollution is always unlawful and, in itself, constitutes a nuisance.

The court granted both damages and an injunction.

\section{Defences to Nuisance}

The main defences that may be advanced by a defendant to justify conduct that would otherwise be considered an actionable nuisance - either private, public, the rule in Rylands v. Fletcher, or riparian - are prescription, acquiescence or laches, and statutory authority, of which the last mentioned is the most important in the context of this paper. ${ }^{208}$

The gist of this defence is that if the legislature directs a thing to be done that would otherwise give rise to an action, the right of action is removed by the legislative direction. As stated in Managers of the Metropolitan Asylum District v. Hill: ${ }^{180}$

It is a reductio ad absurdum to suppose it [Parliament] left in the power of the person who had the cause of action to obtain an injunction and so prevent the doing of that which the legislature intended to be done at all events.

While the above words are rather general, the principles evolved, as reflected in recent cases, are as follows. Where the legislation authorizing the defendant's action is permissive (as to how such action is to be pursued), as opposed to mandatory, the cases clearly show that the common law rights are not to be abridged; Lawrysn v. Town of Kipling. ${ }^{200}$ The courts will not accept the defence unless the legislation provides, or otherwise shows, an express intent to abrogate private rights, following the well known rule, without expressly alluding thereto, that statutes in derogation of the common law will be strictly construed. In Groat v. Edmonton, it was stated that insofar as: ${ }^{201}$

statutory powers are concerned, they should not be understood as authorizing the creation of a private nuisance - unless indeed the statute expressly so states.

Also, in the case of Connery v. Government of Manitoba, it was decided by the court, without specific review of any statutes involved therein (except perhaps to approve of the lower court's finding in that respect), that since pollution was always unlawful and actionable, and since it was incumbent upon the government that public works must be executed so as not to interfere with private rights, the defence of statutory authority could not be maintained.202 Where the legislation authorizing the defendant's operation is mandatory, the defendant must show that the nuisance complained of is the result of the necessary or inevitable consequences of the defendant's activities pursuant to the direction

108 [1928] S.C.R. 522.

197 Id. at $527-535$.

${ }^{108}$ For more extensive treatment of the above, see Fleming, supra, n. 163 at 365 and McLaren, Nuisance Actions, supra, n. 157 at 543.

199 (1881) 6 A.C. 193 at 203.

200 (1965) 55 W.W.R. 108 at 110.

${ }^{201}$ Supra, n. 196, and see Portage La Prairie v. B.C. Pea Growers, supra, n. 188 at 481. 202 (1970) 75 W.W.R. 289 at 298-297. 
and authorization of the legislation. ${ }^{203}$ The "inevitability" of such action by defendants is a question of fact by the court, but generally it has been expressed as: ${ }^{204}$

The manner in which the act was done was the only manner in which it could be performed, having due regard to existing scientific knowledge and practical feasibility.

While it would seem from the wording that negligence rules apply, the courts are apparently requiring a high standard of conduct by defendants which, for practical purposes, is not far removed from strict liability rules. In the above cases, the discharge of effluent or the alteration of the quality of water was not such an inevitable result of the legislation considered in them to allow the defence to stand. In Howrish v. Holden, the court exhibited a wide latitude in its finding as to the non-inevitability of the defendant's discharge of the sewage disposal resulting in an incidental pollution and therefore interference of plaintiff's riparian rights: ${ }^{205}$

In suggesting . . . that the necessity or inevitability of the annual draining of the defendant's lagoon constitutes a defence to the plaintiff's action, I assume that he asks the court to find that since the construction of the sewage disposal system is a work authorized by statute, as it undoubtedly was, the discharge into the plaintiff's land was the necessary result of such authorized works. No instrument or board of health certificate evidencing or authorizing the release of effluent water into the plaintiff's land was adduced and I decline to find as a fact that the construction of the defendant's sewage system of necessity or inevitability included as a component part thereof the use of the plaintiff's land as a discharge area .... How the defendant's sewage system is to be operated without injury to the plaintiff is for the defendant to discover.

From the wording above, it would seem necessary that any authorization to maintain a nuisance must specifically describe and include the overriding of plaintiff's rights.

The Trial Court in B.C. Pea Growers ${ }^{206}$ found as a matter of fact that offensive and noxious odours emanating from the defendant's operation of the lagoon, for a considerable period of each year, were necessarily incidental and the inevitable result of the lagoon's operation, notwithstanding evidence submitted that noxious offensive odours could perhaps be reduced with the addition of certain chemicals.

As a parting comment, it is obvious that the various statutes which could be involved in the wide variety of petroleum activities giving rise to environmental litigation cannot be dealt with here as to whether they are permissive or mandatory, authorize expressly or implicitly, or provide that common law rights are specifically abrogated in a given situation. Each statute must be looked at individually to determine whether it will provide a defence. As an indication of the divergence of opinion in predicting that certain statutes may or may not offer a good defence, the following is offered. It has been suggested that in the case of gas plants emitting noxious, odorous or toxic gases, an argument may be made that under various regulations and Acts statutory authorization may be a good defence to a nuisance action, ${ }^{207}$ but that the argument would probably not succeed in the case of waterflood pressure maintenance

203 Stephens v. Richmond Hill, supra, n. 193; Portage La Prairie, supra, n. 188.

204 Lawrysyn, supra, n. 200 at 112.

205 Supra, n. 190 at 497.

206 (1963) 45 W.W.R. 513 at 531-532.

207 Curran, supra, n. 152 at 16-19. 
schemes pursuant to various regulations, ${ }^{208}$ nor in the case of onshore or offshore blowouts and oil spills as a result of activities authorized under various Acts and regulations. ${ }^{209}$

The above defence may be further confused by the introduction of pollution control acts in every province, and federally throughout Canada, allowing or permitting pollution in various circumstances. The tests as enunciated over the years and recently used as in the cases above must be applied in each case to discover whether a good defence can be found.

\section{Negligence}

For the most part, common law environmental actions are brought against defendants under the various heads of nuisance as discussed above. Negligent conduct is not required to establish liability in nuisance. It is generally the consequences of the act, and not the act itself, which are looked at in nuisance cases in Canada. Thus, most so-called environmental suits have not been brought as negligence actions since proof that the defendant's conduct falls below some prescribed duty of care is usually difficult, and the issue of damages has been qualified by the problems of foreseeability and remoteness. ${ }^{210}$

However, negligence may play an important part in those actions wherein the defendant claims the defence of statutory authorization to traditional nuisance actions as previously discussed. Even where the defendants have acted pursuant to legislation which has been found to be mandatory, rather than permissive, there is a duty, express or implied, to act with all reasonable precaution in carrying out such directives.

Thus, in the recent case of Tahsis Company Ltd. v. Canadian Forests Products $L t d .{ }^{211}$ it was held that although in the usual case the rule in Rylands v. Fletcher applied to an escape of fire from defendant's lands, the rule did not apply where the damage was a result of activities performed pursuant to an order issued under valid legislation. ${ }^{212}$ However, the defendant was required to "use all reasonable precautions to prevent escape of fire or damage to property". ${ }^{213}$ The burden of proof was on the "statutory undertaker or the person authorized by statute to burn, to prove that such power was exercized without negligence."214 In this particular case, dealing with fire, the court cited with approval the following words: ${ }^{215}$

I would go so far as to say that in a case of the present class no precaution which was commercially practicable ought to have been omitted, and any omission of a practicable precaution would constitute a failure of duty.

The usual rules of negligence apply to operations such as drilling, reclamation, etc. within one's own land that may result in some environmental damage to property. The author does not intend to canvass these cases, nor to enunciate the rules further since others have covered this ground.

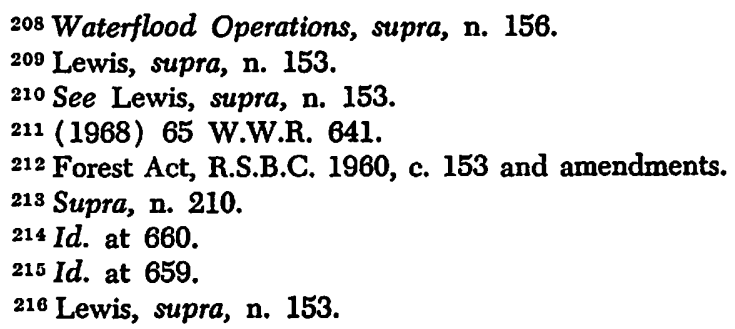


6. Trespass

.. There is relatively little activity in this field insofar as environmental suits are concerned, and one leading writer has dismissed this cause of action as an effective or important area of the common law for future consideration. ${ }^{217}$

\section{CONCLUSION}

The various areas of law and the cases reviewed herein lead to the conclusion that the direction of Canadian law with respect to the environment will be mostly in the legislative field.

The common law actions become important where the statutes do not provide for civil liability, but generally include provisions expressly precluding the statutes as defences to such actions. Since the areas in which most petroleum activities take place are for the most part presently remote, the usual private nuisance actions are likely to be infrequent. Although potentially troublesome, public nuisance actions are too restricted to cause any significant wholesale interest in its promotion.

The matter of standing to sue by private citizens, whether in the public nuisance suits or under various environmental statutes, is probably the single most important reason for the low number of environmental suits in Canada. The administrative agencies exercising quasi-judicial powers in enforcing the various Acts are currently the center of attention. Although there are extensive discretionary powers in the agencies, there has largely been co-operation by the industry with these bodies throughout the most recent period of environmental conflict.

To the extent that further environmental legal activity in the form of more legislation, or greater enforcement of existing legislation, encroaches on the ability of the industry to produce more petroleum at a publicly acceptable price, there may well be a temporary retreat from rapidly advancing environmental legal considerations. However, this field of law should not be ignored or submerged as being unimportant since the balancing of respective values energy required versus environmental protection - has by no means been determined or settled.

217 Supra, n. 157. 